DOI: 10.34015/2523-4552.2021.3.09

УДК 342.57

Балтаджи П. М.,

кандидат юридичних наук, доцент, професор кафедри державно-правових дисциплін Одеського державного університету внутрішніх справ ORCID: 0000-0003-2346-4230

\title{
БОЛГАРИ БЕССАРАБІЇ: ІСТОРИКО-ПРАВОВИЙ НАРИС
}

Стаття представляє ілюстрацію історії переселення болгарського народу та формування національної карти Бессарабії. Історія міста, яке вже 200 років зберігає статус національного центру і $€$ зразком духовно-культурного розвитку болгарських колоній на півдні України у XIX ст. Розглянуто основні аспекти економічного, національно-культурного та соціального розвитку болгарської діаспори. Імена і біографія видатних людей, наукові гіпотези та факти історії, відтворюють національну картину державного будівництва та політики влади на півдні України. А аналіз національної ментальності регіону, дає відповідь, щодо інструментів діалогу з національними меншинами, методів регіональної політики та поваги до історичної пам'яті.

Ключові слова: болгари; Бессарабія; колонії; Болград; національнокультурна спадщина; національна ментальність; I. М. Інзов.

Статья представляет иллюстрацию истории переселения болгарского народа и формирование национальной карты Бессарабии. История города, который уже 200 лет, сохраняет статус национального центра и является примером духовно-культурного становления болгарских колоний на юге Украины в XIX в. Рассмотрено основные аспекты экономического, национально-культурного и социального развития болгарской диаспоры. Имена и биографии известных людей, научные гипотезы и факты истории, воссоздают картину государственного строительства и политики властей на юге Украины. Характеристика национальной ментальности региона, может стать подсказкой в выборе инструментов диалога с национальным меньшинством, методов региональной политики.

Ключевые слова: болгары, Бессарабия, Болград, национально-культурное наследие, национальная ментальность, И. М. Инзов.

Постановка проблеми. Сьогодні, в умовах зміни загальнонаціональної стратегії, внутрішніх державно-політичних процесів, регіонально-економічних трансформацій, має змінитись підхід до регіональної політики. В останні роки, посилились протиріччя у взаємовідносинах центральних та регіо- нальних органів виконавчої влади та органів місцевого самоврядування на всіх рівнях управляння, щодо діалогу у вирішенні регіональних проблем. Водночас, регіональна політика, об'єктивно стає основним інструментом регулювання економічного розвитку, особливо в тих сферах, де дія ринкових важелів об- 
межена (соціальна, екологічна, наукова, освітня) [1, с. 19]. Все частіше предметом міжнародного діалогу стають питання інтересів певних національних та етнічних груп в Україні. Питання захисту національної самобутності, мови, культури, історії регіонів, стає темою політичних дискусій, а іноді, навіть маніпуляцій.

Саме регіональна політика, може стати універсальним інструментом примирення і діалогу, запорукою збереження національнокультурної спадщини регіонів, в контексті цілісної історико-правової картини держави.

Законом України «Про засади державної регіональної політики» державна регіональна політика визначена як система цілей, заходів, засобів та узгоджених дій центральних і місцевих органів виконавчої влади, органів місцевого самоврядування для забезпечення високого рівня якості життя людей на всій території України 3 урахуванням природних, історичних, екологічних, економічних, географічних, демографічних, та інших особливостей регіонів, їх етнічної і культурної самобутності [2].

Дороговказом у побудові діалогу з регіонами може стати знання історичних передумов їх формування. Розуміння специфіки регіону, його історії та національної ментальності і $\epsilon$ ключем до політичного порозуміння Предметом даного дослідження $є$ національна специфіка Бессарабії та історичний досвід державної регіональної політики, щодо болгарських переселенців на цих територіях у XIX ст.

Аналіз останніх досліджень та публікацій. Протягом століть, культурно-історична спадщина болгарського народу привертає увагу істориків, етнографів, соціологів, лінгвістів і дослідників аматорів. Перший системний аналіз історії Новоросійського краю був проведений одним із засновників Одеського товариства історії і старожитності, секретарем канцелярії Новоросійського генерал-губернаторства А. О. Скальковським. Зібраний документальний матеріал склав основу подальших досліджень, присвячених болгарській діаспорі.

Вагоме місце серед широкого кола наукових досліджень займають праці М.С.Державіна, Ю. І. Венеліна, Д. Д. Димитрова, С. Б. Бернштейна, В. Ф. Шишмарьова, які у різні періоди аналізували історичні джерела, специфіку і закономірність поширення болгарської мови. Значна кількість етнографічних досліджень формують уявлення про культуру, побут і традиції народу. Історія господарського розвитку болгарських колоній була предметом досліджень I. I. Мещерюка, I. А. Анцупова, М. М. Максименко. Військовий статус і роль переселенців у визвольній боротьбі визначали в своїх роботах А. Б. Бачинській, I. Ф. Грек. У контексті української історії болгарське питання представлено в роботі 0. А. Бачинської [3]. Комплексна картина досліджень, присвячених різним аспектам російсько-болгарських відносин, починаючи 3 середини XIX ст., представлена в роботі О. В. Бєлової [4]. у 2010- х роках розпочато системну роботу зі встановлення прямих ареалів виходу болгар до Бессарабії. Значна частина праць останнього десятиліття, присвячена історії зміни статусу бессарабських земель у XX ст. [5; 6] 
Особливе місце в історіографії періоду, займають біографічні дослідження присвячені ключовим постатям. Так, вагомим внеском у дослідження історії болгарського переселення, стала робота М.В.Агбунова «Генерал-попечитель» - життєвий опис I. М. Інзова, i'мя якого свято для Бессарабії і уособлює іï історію [7].

Постановка завдання. Метою статті $\epsilon$ історико-правовий огляд формування й трансформації етнокультурної спільноти болгар Бессарабії у XIX ст., характеристика державної політики щодо регіону 3 урахуванням національнокультурних пріоритетів.

Виклад основного матеріалу. Багатонаціональний характер населення - одна з визначальних рис південного регіону України. На цій території компактно проживають представники більш ніж 30 національностей. Заселенню міст регіону сприяла міграційна політика Катерини II. Указ від 22 липня 1763 р. дозволяв усім іноземцям селитися в губерніях або пустопорожніх землях, надавав право створювати колонії, містечка, будувати церкви і дзвіниці, звільняв від податків та військової служби. В цьому ж році створено Канцелярію опікунства іноземних колоністів 3 річним бюджетом 200 тис. рублів.

Сучасний етнічний склад регіону почав формуватися у XVIII ст. під впливом боротьби Балканських народів проти Османської імперії. Індивідуальні переселення 3 болгарських територій з часом набули масових масштабів і поклали початок організації перших утворень компактного проживання болгар. Вихідці з різних регіонів Болгарії, в силу економічних, політичних, релігійних причин, змушені були покинути рідні місця.

Новий епізод російськотурецького протистояння, зростання політичної свідомості, бажання зберегти етнічну ідентичність і досягти національно-релігійної свободи, зумовив нову хвилю еміграції на початку XIX ст.

Як зазначає О. І. Ганчєв, процес формування групи болгар у Бессарабії відбувається протягом трьох етапів, початок яких збігається 3 російсько-турецькими війнами XIX cт. Перший етап розпочинається під час війни 1787-1791 pp. Переселенці першої хвилі (близько 200 болгарських сімей) названі «туканцями», тобто «місцевими». Другий етап формування групи, зумовлений соціально-економічними наслідками війни 1806-1812 pр. Це період масового переселення християнського населення до Бессарабії, коли докорінно змінюється етнодемографічна ситуація в регіоні. На 1819 рік у Бессарабії мешкає 2294 сім'ї давніх переселенців і 4238 сімей тих, які прийшли після 1806 року. Третій етап масового переселення болгар до Бессарабії спричинений подіями російськотурецької війни 1828-1829 рр. Як результат, у Буджаку селиться близько 25 тис. болгар. Фактично, у 1835 p. болгарська колонізація Південної Бессарабії була завершена, хоча поодинокі випадки переселення болгар до Буджака траплялися i пізніше [8, с.11].

Розселення емігрантів 3 болгарських земель у західному куті (саме так турецькою перекладається «буджак») Російської імперії, на просторах Буджакського степу, отрима- 
ло в історії назву «болгарське оселення».

Бухарестський мирний договір (1812 р.) визначив майбутнє південного краю Російської імперії. За перші два десятиліття XIX ст. болгарська діаспора стала органічною частиною бессарабського суспільства. Поряд з гагаузами, молдаванами, греками, німцями, переважну більшість складали болгарські колонії. Формально, колонії не залежали від губернії і підпорядковувались Опікунському комітету іноземних поселенців південного краю Російської імперії і особисто його голові Івану Микитовичу Інзову.

Участь у військових подіях на Балканах, назавжди зв'язала I. M. Інзова 3 болгарським народом. Він зарекомендував себе не лише досвідченим воєначальником, а й мудрим, далекоглядним політиком, державним діячом. Опіку і піклування долею задунайських переселенців в Бессарабії, I. М. Інзов вважав своїм громадянським обов'язком. До останніх днів свого довгого життя, генерал займався благоустроєм Бессарабії і проблемами болгарських переселенців.

Нова батьківщина дала переселенцям гарантію безпеки, особисту свободу і простір для господарювання. Указ «Про поселення в Бессарабській області болгар та інших задунайських переселенців», виданий Олександром I 29 грудня 1819 р., визначив соціально-економічний, правовий і адміністративний статус задунайських переселенців. Колоністи звільнялись від рекрутської повинності, їм було надано право вільної торгівлі. Закон визначав категорії переселенців, яким в залежності від часу переселення надава- лись фінансові і земельні привілеї. Набула нормативного визначення територія розселення болгар. До складу Бессарабської області увійшли чотири округи: Прутський, Кагульський, Ізмаїльський і Буджацький.

Російський уряд відводив болгарам особливу роль, як у балканському питанні, так і у питанні освоєння південних земель і поширення православної віри. Проявом вдячності болгарського народу, стала наполеглива, повсякденна праця, яка перетворила цілинні землі у економічно благодатний регіон.

I хоча, національно-культурний розвиток колоністів, не був предметом опіки Російської влади, болгарському народу вдалось зберегти мову, національну ментальність, досвід господарювання, вірування, звичаї та традиції пращурів. Минули століття, змінилось не одне покоління, а болгарська мова продовжує звучати в різних регіонах України.

Менталітету як духовноінтелектуальному феномену, притаманна динаміка і універсальність. Богобоязливі, сором'язливі, працьовиті і невимогливі у побуті болгари, впевнено увійшли у етнічний простір регіону. Закріпившись на території Новоросії і Бессарабії, болгари склали особливу частину слов'янського соціуму. Національний менталітет вбирає в себе зміст етнопсихологічних i етноідеологічних чинників, нерозривно пов'язаний з історичними умовами розвитку нації. Історична доля, традиційно представляється як вирішальний чинник формування основних ідей життя. Мова йде про вирішальну роль історичного контексту у формуванні національного обличчя [9, с. 23]. 
Посилаючись на негативну оцінку ролі Росії в історії болгар, надану в роботі активного учасника болгарського національно-визвольного руху Г.С. Раковського «Переселення болгар в Росії чи пагубна російська політика по відношенню до болгар», сучасні дослідники визнають необ'єктивність науковоісторичних характеристик політики російського уряду відносно іноземних колоній. У ідеологічному контексті, неоднозначність внутрішньої політики та питання про негативні наслідки переселення болгар в Росію, відверто ігнорувалось [4].

Сьогодні, в умовах появи в містах етно-культурних центрів, популяризації болгарської культури, запровадження етнічних фестивалів, з одного боку, і фактичної втрати національного болгарського села 3 іншого, варто звернути увагу на історію невеличкого міста Болград, на півдні Бессарабії, яке по праву, вже 200 років зберігає статус столиці бессарабських болгар.

Місто було закладено у $1821 \mathrm{p}$. на березі озера Ялпуг, поблизу болгарського поселення Табакі, 3 ініціативи намісника Бессарабії, головного попечителя і голови Комітету іноземних поселенців Південного краю Російської імперії І. М. Інзова, відповідно до попереднього плану інженер-майора С. М. Малевенського. Його назва [від болг. - «бол» достаток, «град» місто], яскраво характеризувала плани задунайських болгар. Ідея болгарських переселенців про створення міста була підтримана Указом Олександра I від 29 грудня 1819 р. і реалізована через три роки. Дуже швидко тут з'явились широкі вулиці 3 новими кам'яними будинками, площі 3 торговими лавками, міський парк 3 фонтанами, згодом названий на честь О.С. Пушкіна, який у липні 1823 р. відвідав місто. Активний розвиток сільського господарства, торгівлі, ремісництва, сприяли економічному розвитку міста.

У 1840 р. кількість населення, яке складали переважно переселенці 3 болгарських міст Слівен і Ямбол, становила 5000 осіб. Разом 3 тим, слід сказати про складні і незвичні для переселенців кліматичні умови, які стали серйозним випробуванням терпіння, волі і затятості - національних рис болгарського народу.

Головною силою, що піднімала болгар на боротьбу, підтримувала у освоюванні нових земель i об'єднувала покоління, завжди залишалась православна віра. Збереження духовно-культурних традицій визначило сутність всього життя болгарського народу.

Символом віри, свободи i візитною карткою міста, став закладений у 1820 р., СпасоПреображенський Собор. Архітектор А. І. Мельников запропонував проект, представлений на конкурсі проектних робіт Іссакієвського Собору в Петербурзі. Протягом 17 років, під особистим керівництвом I. М. Інзова і наглядом спеціальної комісії, у складі міських купців, тривало будівництво. Було витрачено 750 тис. народних рублів. Близько 10 тис. колоністів взяли участь у роботах. Кожен мешканець міста i близьких селищ вважав обов'язком докласти власну частку у велику справу. Наприкінці 1837 року роботи були завершені. Купол, висотою більш ніж 50 метрів, мав стати маяком міста. Дзвін-благовіст, спеціально виготовлений у Москві, голосом 
його мешканців. Собор вміщував 3 тис. прихожан i повністю відповідав архітектурним традиціям нового міста. 15 жовтня 1838 р. преосвященний Дмитро архієпископ Кишинівський і Хотинський, у присутності вірменського архієпископа Нерсеса, генерала І. М. Інзова, почесних гостей і мешканців міста, освятив Спасо-Преображенський Собор. Подія стала народним святом [10].

Слід звернути увагу на просвітницьку функцію церкви. Богослужіння здійснювалось старослов'янською, російською і болгарською мовами. Не одне покоління священників брало участь у духовноморальному вихованні болгарської діаспори. Популяризація російської мови, возвеличення царівімператорів, не стали на заваді збереженню історичної пам'яті. Історія собору невід'ємна від історії міста. Змінювались часи, влада і режими, гриміла війна і землетруси, а вони стояли. Пожежа у СпасоПреображенському соборі у січні 2012 р. стала бідою і болем для усіх болгар. Подія знову об'єднала мешканців буджакських земель.

Храм Св. Митрофана був закладений 3 дозволу Духовної консисторії 25 травня 1840 р. Будівництво здійснювалось за рахунок прихожан центрального кафедрального собору і тривало три роки. 3 квітня 1844 р. церква була освячена. Після смерті I. М. Інзова, якого по праву вважали батьком усіх бессарабських болгар, і отримання дозволу на перевезення його праху до Болграду, саме цей, невеличкий за розміром і простий в оформленні храм, був обраний як усипальницямавзолей і став останнім притулком генерала Інзова. Вдячні болгари на руках пронесли тіло генерала більш ніж 200 км., а відстань від воріт цвинтаря до храму пройшли на колінах. Цей історичний факт став частиною історії бессарабських болгар, яку і сьогодні батьки переказують дітям.

Основним осередком національно-культурного відродження болгар стало центральне училище ім. Св. Кирила і Мефодія (Болградська гімназія). Перша приватна однокласна школа відкрилась в Болграді у 1821 р., за активного сприяння I. М. Інзова. Серед навчальних закладів, значне місце відводилось училищу при СпасоПреображенському соборі, відкриття якого відбулось у 1832 р. Згодом, тут було відкрито жіночі класи і землемірне відділення, однак це не вирішило питання професійної підготовки.

I якщо у болгарських навчальних закладах Криму, незалежно від типу навчання, болгарська мова не вивчалась, а навчання проводилось виключно російською мовою, то учні училищ і шкіл Бессарабії, були у значно вигіднішому положенні [11, c 9].

Висновки. В залежності від забезпеченості національно-культурного інтересу та політичного режиму, історія освіти в Болграді представлена трьома періодами: болгарським (1858-1886), російським (1887-1918) i румунським (19181940) [12, с. 194]. Значним результатом першого періоду стало піднесення національного духу, зростання уваги до болгарської історії, мови, літератури, підготовки молоді, яка в майбутньому склала основу інтелігенції вільної Болгарії. Опинившись у складі Молдавського 
князівства, бессарабські болгари не полишали давню ідею відкриття центрального училища у м. Болграді. у 1858 р. завдяки посередництву Г. С. Раковського молдавський князь Ніколо Богороді підписав Указ Про відкриття першого болгарського середнього навчального закладу. Центральне училище стало Болградською гімназією № 1. Навчання в гімназії проводилось болгарською і румунською мовами. Православна віра була єдиною вимогою для абітурієнтів. При гімназії було відкрито бібліотеку, пансіонат, діяла власна типографія, оркестр, хор, театральний колектив. Важливу роль у цей період, історія відводить директорам шкіл: одному з засновників Болгарської Академії Наук С. Радулову, Д. Мутєву, Г. Мірковичу та ін. Вони проводили серед учнів активну просвітницьку діяльність, сприяли національно-патріотичному вихованню [13, с. 93].

Другий період характеризується втратою національних ознак освіти, закриттям бібліотек, продажом типографії, факультативним викладанням болгарської мови, вве- денням вступних іспитів, обмеженням прав Опікунського комітету.

Третій період пройшов під гаслом румунізації освіти, гімназію перейменовано у ліцей короля Карла II. Навчання проводилось румунською мовою, запрошеними 3 Румунії викладачами. Разом і з тим, у цей період, болгарське місто Болград, стає другим, після Кишиніва, літературно-культурним центром Бессарабії.

Гортаючи сторінки історії, можна давати оцінки, згадувати події, називати імена й шукати нові факти, але головне - бачити в історії майбутнє. Пам'ять, віра і повага до минулого народів, і $\epsilon$ нашою духовно-культурною спадщиною, підказкою ментального коду, інструментом налагодження соціальних комунікацій у багатонаціональному суспільстві, принципом регіональної політики. Історія одного регіону, одного міста, одного народу $є$ свідченням того, що в історії не може бути дрібниць i беззаперечними стовпами у фундаменті нації, в усі часи залишаються: історична пам'ять, віра в людей, увага до освіти, державний авторитет.

\section{Список використаних джерел}

1. Гончаров Ю. В. Проблеми регіональної політики в Україні. Економіка та держава. 2017. № 2. С. 19-21.

2. Закон України «Про засади державної регіональної політики. Відомості Верховної Ради (ВВР). 2015. № 13. Ст. 90.

3. Бачинська О. Українське населення Придунайських земель XVIII - початок $\mathrm{XX}$ ст. (заселення й економічне освоєння). Одеса : Астропринт, 2002. 328 с.

4. Белова Е. В. Внутренняя политика российского правительства по заселению юга Российской империи (по материалам Новороссии и Бессарабии 1751-1871 годы). Москва : РГТУПС. 2004. 254 с.

5. Адамчук I. Боротьба за державно-територіальний статус Північної Буковини, Аккерманського, Ізмаїльського і Хотинського повітів Бессарабії, острова Зміїного та Закарпатської України в 1917-1947 рр. Історико-правове дослідження : монографія. Київ : Атіка, 2007. 160 с. 
6. Губань Р. В. Входження Бессарабії та Північної Буковини до складу Румунії (історико-правовий аспект). Наукові записки Інституту законодавства Верховної Ради Украӥни. 2014. № 2. С. 5-8.

7. Агбунов М. В. Генерал-попечитель (Жизнь и деятельность И. Н. Инзова). Арциз: «Диамант», 2009. 384 с.

8. Ганчєв О.ІІ. Демографічні трансформації болгарської спільноти південної Бессарабії (XIX - поч. XXI століть): автореф. дис. д-ра іст. наук. Запорізький нац. ун-т. Запоріжжя. 2020. 39 c.

9. Балтаджи П. М. Поняття "ментальність" у сучасних наукових дослідженнях. Актуальні проблеми політики. 2012. Вип. 45. С. 21-28.

10. Православные храмы в болгарских и гагаузских селениях юга Украины и Молдовы: юбилейный сб. по случаю 170-летия со дня заложения и 165-летия со дня освящения Болградского Спасо-Преображенского собора. / ред. И.М.Пушков. Болград. 2004. 298 с.

11. Канишева М. А. Развитие начального образования болгарских переселенцев Крыма в конце XIX начале XX столетия. Таврійський вісник освіти. Науковометодичний журнал. 2005. № 4 (12). С.9-23.

12. Пушков I. Новоросійський університет і Болградська гімназія: україноболгарські зв'язки. Рідна мова - запорука безсмертя нацї: матеріали Міжнар. наук.-практ. конф. (Одеса, 20-23 жовт. 1998 р.). Київ : Книжкова палата України, 1999. $200 \mathrm{c}$.

13. Челак Е. И. Българското национално образование в Руска и Румънска Бесарабия: опит за съпоставане върху примера на Българската гимназия и Комратското централно училище (1856-1878). Болградската гимназия. Сборник по случай 135годишнината от основането. София, 1993. С. 90-99.

\section{References}

Goncharov, Yu. V. (2017). Problemi regionalnoyi politiki v Ukrayini. Ekonomika ta derzhava, 2, 19-21.

Bachinska, O. (2002). Ukrayinske naselennya Pridunajskih zemel XVIII - pochatok XX st. (zaselennya j ekonomichne osvoyennya). Odesa: Astroprint.

Belova, E. V. (2003). Vnutrennyaya politika rossijskogo pravitelstva po zaseleniyu yuga Rossijskoj imperii (po materialam Novorossii i Bessarabii 1751-1871 gody). Moskva : RGTUPS.

Adamchuk, I. (2007). Borotba za derzhavno-teritorialnij status Pivnichnoyi Bukovini, Akkermanskogo, Izmayilskogo i Hotinskogo povitiv Bessarabiyi, ostrova Zmiyinogo ta Zakarpatskoyi Ukrayini v 1917-1947 rr. Istoriko-pravove doslidzhennya. Kiyiv: Atika.

Guban, R. V. (2014). Vhodzhennya Bessarabiyi ta Pivnichnoyi Bukovini do skladu Rumuniyi (istoriko-pravovij aspekt). Naukovi zapiski Institutu zakonodavstva Verhovnoyi Radi Ukrayini, 2, 5-8. amant».

Agbunov, M. V. (2009). General-popechitel (Zhizn i deyatelnost I. N. Inzova). Arciz: «Di-

Ganchyev, O. I. (2020). Demografichni transformaciyi bolgarskoyi spilnoti pivdennoyi Bessarabiyi (XIX - poch. XXI stolit): avtoref. dis. d-ra ist. nauk. Zaporizkij nac. un-t. Zaporizhzhya.

Baltadzhi, P. M. (2012). Ponyattya "mentalnist" u suchasnih naukovih doslidzhennyah. Aktualni problemi politiki, 45, 21-28.

Pravoslavnye hramy $v$ bolgarskih i gagauzskih seleniyah yuga Ukrainy i Moldovy: yubilejnyj sb. po sluchayu 170-letiya so dnya zalozheniya $i$ 165-letiya so dnya 
osvyasheniya Bolgradskogo Spaso-Preobrazhenskogo sobora. / red. I. M. Pushkov. Bolgrad. 2004. $298 \mathrm{~s}$.

Kanisheva, M. A. (2005). Razvitie nachalnogo obrazovaniya bolgarskih pereselencev Kryma v konce XIX - nachale XX stoletiya. Tavrijskij visnik osviti. Naukovo-metodichnij zhurnal, 4 (12), 9-23.

Pushkov, I. (1999). Novorosijskij universitet i Bolgradska gimnaziya: ukrayinobolgarski zv'yazki. Ridna mova - zaporuka bezsmertya naciyi: materiali Mizhnar. nauk.prakt. konf. (Odesa, 20-23 zhovt. 1998 r.). Kiyiv: Knizhkova palata Ukrayini.

Chelak, E. I. (1993). Blgarskoto nacionalno obrazovanie v Ruska i Rumnska Besarabiya: opit za spostavane vrhu primera na Blgarskata gimnaziya i Komratskoto centralno uchilishe (1856-1878). Bolgradskata gimnaziya. Sbornik po sluchaj 135godishninata ot osnovaneto. Sofiya, 90-99.

P. Baltadji, PhD in Law, Associate Professor, Educational and Scientific Institute of Law and Cybersecurity, Odessa State University of Internal Affairs

ORCID: 0000-0003-2346-4230

\section{The Bulgarians of Bessarabia: the historical legal essay}

The article illustrates the history of the resettlement of bulgarian people and Bessarabia map formation. The history of the city, which has been maintaining the status of the National Center for 200 years - is an example of spiritual and cultural development of the Bulgarian colonies in the south of Ukraine in the XIX century. The main aspects of the economic, national, cultural and social development of the bulgarian diaspora are analyzed. The names and biographies of outstanding people, scientific hypotheses and facts of history reproduce the national picture of state formation and government policy in the south of Ukraine. The analysis of the national mentality of the region gives an answer to the tools of dialogue with national minorities, methods of regional policy and respect for historical memory. Having gained a foothold on the territory of Novorossiya and Bessarabia, bulgarians formed a special part of Slavic social environment.

The purpose of the article is a historical and legal review of the formation and transformation of the ethno-cultural community of bulgarians in Bessarabia in the XIX century. Characteristics of State policy to the region, taking into account national and cultural priorities.

Knowledge of the historical prerequisites for the formation of regions can become a guide in building a dialogue with the regions. Understanding the specifics of the region, its history and national mentality is the key to political understanding the subject of this study is the National specifics of Bessarabia and the historical experience of State regional policy on bulgarian immigrants in these territories in the XIX century.

Flipping through the pages of history, you can evaluate, remember events, call out the names and seek out new facts, but the main thing is to see the future in history. Memory, trust and respect for the past of nations - is our spiritual and cultural heritage, a hint of the mental code, a tool for establishing social communications in a multinational society and the principle of regional policy. The history of one re- 
gion, one city, one nation is evidence that there can be no minor things in history; indisputable pillars in the foundation of the nation, at all times remain: historical memory, faith in people, attention to education, state authority.

Keywords: bulgarian; Bessarabia; colonies; Bolgrad; national mentality; cultural memory; I. M. Inzov. 